Article

\title{
Carbon-Supported Copper-Based Nitrogen-Containing Supramolecule as an Efficient Oxygen Reduction Reaction Catalyst in Neutral Medium
}

\author{
Yuanyuan Zhao ${ }^{1}$, Ya Chu ${ }^{1}$, Xiuping Ju ${ }^{2}$, Jinsheng Zhao ${ }^{1, *(1)}$, Lingqian Kong ${ }^{2}$ and Yan Zhang ${ }^{1}$ \\ 1 Department of Chemistry, Liaocheng University, Liaocheng 252059, China; zhaoyuanldfx@163.com (Y.Z.); \\ chuyaya19950621@126.com (Y.C.); zhang_yan1219@126.com (Y.Z.) \\ 2 Dongchang College, Liaocheng University, Liaocheng 252059, China; jxp1127@163.com (X.J.); \\ lingqiankong@126.com (L.K.) \\ * Correspondence: j.s.zhao@163.com; Tel.: +86-635-853-9607
}

Received: 19 December 2017; Accepted: 26 January 2018; Published: 30 January 2018

\begin{abstract}
In this work, a nitrogen-containing bidentate ligand named 5,5'-(9-octyl-9H-carbazole2,7-diyl)bis(1,10-phenanthroline) (OCBP) was synthesized as a nitrogen precursor for making an oxygen reduction catalyst. The 1,10-phenanthroline unit provides a coordination site for copper ions, and the resulting $\mathrm{Cu}-\mathrm{N}_{x}$ unit may be responsible for the catalytic activities of the catalyst. Carbon black was selected as a support to improve the electroconductibility of the resulting catalyst. The metallo-supramolecule (Cu-SOCBP) was dispersed on the surface of Vulcan XC-72 carbon and was used as a catalyst (designated as Cu-SOCBP/C) for the oxygen reduction reaction (ORR). The microscope structure and surface components of the catalyst were acquired via scanning electron microscopy and X-ray photoelectron spectroscopy, as well as X-ray powder diffraction. The electrochemical property and ORR mechanism of Cu-SOCBP/C were analyzed using a variety of electroanalytical methods including cyclic voltammetry, electrochemical impedance spectroscopy, and linear sweep voltammetry. These results show that Cu-SOCBP/C was successfully synthesized and that ORR was achieved mainly via a four-electron transfer process to water. Thus, Cu-SOCBP/C was an effective catalyst and might have potential application as a cathodic catalyst in microbial fuel cells, which operate in an aqueous medium.
\end{abstract}

Keywords: supramolecule; ORR activity; kinetics study

\section{Introduction}

Fuel cells are efficient devices that can convert the energy of fuels such as hydrogen or methanol into electricity via an electrochemical reaction with an oxidant such as oxygen in the air. In the fuel cell reaction, oxygen is reduced at the cathode, and hydrogen is oxidized at the anode $[1,2]$. As a newer energy source, fuel cells have broad application prospects because of their high efficiency and cleanness [3]. However, the sluggish reaction kinetics of the oxygen reduction reaction (ORR) that occur on the cathode lead to larger voltage losses, and this might subsequently decrease the energy conversion efficiency of fuel cells [4]. Pt and its alloys are the best choices as oxygen reduction catalysts, but the limited abundance and high cost of Pt restricts the larger-scale commercial use of fuel cells [5-7].

Recently, scientists have been looking for alternatives to platinum catalysts that are also low-cost and high-efficiency. Some non-precious metal catalysts (such as nitrogen-doped carbon (NDC) [8,9], metal-containing NDC materials [10,11], metal oxides [12], alloy [13], and transition metal 
complexes [14-17]) are promising and have broad application prospects in fuel cells. In recent years, transition metal complexes have attracted wide attention because of their low cost, facile preparation process, and competitive catalytic activities compared to these properties of the commercial $\mathrm{Pt}$ catalyst [14-17].

Some transition metals (including iron, cobalt, and copper) are thought to serve as key components of catalysts, and these metal ions can be coordinated with nitrogen pockets of some nitrogen-rich molecules, such as macrocyclic compounds [14-17], phenanthroline [18], terpyridines [19], and $\mathrm{N}$-containing heterocyclic polymers [20]. Transition metal complexes generally have favorable catalytic activity for ORR, and the dispersion, deposition, or doping of these catalysts on carbon support materials substantially enhances ORR activity because of the performance improvements of many aspects of the catalysts. These aspects include high dispersion, conductivity, and an enhanced rate of mass transfer, such as charge transfer, oxygen uptake, and hydrogen uptake on the active site of the catalyst [21-24]. This type of modified catalyst is generally designated as Me- $\mathrm{N}_{x} / \mathrm{C}$, where Me represents the complexed metal ions, $\mathrm{N}_{x}$ refers to nitrogen atoms with complexing ability, and $C$ refers to carbon materials as the supporters of the supramolecule complex. In recent years, $\mathrm{Me}-\mathrm{N}_{x} / \mathrm{C}$-type catalysts have shown great potential in the practical operation of various fuel cells [25]. At present, some organic complexes formed between transition metal ions and nitrogen-containing chelating compounds have been prepared, showing an ORR catalytic performance rivaling or better than that of the Pt-based catalysts [24,25].

As a bidentate ligand, phenanthroline (phen) and its derivatives have frequently been used to construct transition metal complexes as ORR catalysts because of their high affinity for metal ions and commercial availability with low cost [26]. Recently, we immobilized the phen unit within conductive polymers via a covalent linkage, which was then composited with carbon powder to form a composite catalyst showing comparable ORR performance with respect to the $\mathrm{Pt} / \mathrm{C}$ catalyst. The extended conjugation length of the polymer is beneficial to enhance the adsorption effect between the polymer and carbon materials through a $\pi-\pi$ interaction, and ultimately lead to improvement in ORR activity [17].

In this work, a novel bis-phen ligand was designed and synthesized by linking two phen units with carbazole as a spacer. In addition, a metallo-supramolecule polymer was prepared from the bis-phen ligand and copper ion(II), which then was composited with carbon powder to give a composite ORR catalyst. The ORR ability of the catalyst was studied in detail in phosphate buffer, a media often employed by the microbial fuel cell. The results showed that the copper-based coordination polymer might be considered as a potential candidate for an ORR catalyst for microbial fuel cell (MFC) applications.

\section{Results and Discussion}

\subsection{SEM and Physisorption}

The stability and catalytic activity of the catalyst depend largely on the surface microstructure and elemental compositions, and knowing these things can help in understanding the oxygen reduction mechanisms of the catalyst $[3,17]$. Therefore, SEM images of both carbon black and the Cu-SOCBP/C catalysts were recorded and are shown in Figure 1. As shown in Figure 1a, the microstructure of carbon was primarily spherical particles, and the irregular accumulation of these particles led to the formation of a porous microstructure on the surface of the carbon black. As clearly seen in Figure 1a, the average radius of the carbon particles is about $35-60 \mathrm{~nm}$. However, the morphology of the Cu-SOCBP/C catalyst is markedly different from that of black carbon, which served as the supporting material for the preparation of the catalyst. The obvious changes in the microstructure of $\mathrm{Cu}$-SOCBP/C are found when comparing with that of carbon black (Figure 1b), and the aggregation of the catalyst might be caused by interactions between Cu-SOCBP and carbon black. The microstructure of the carbon powder is preserved to a certain extent in the Cu-SOCBP/C composite. As previously reported, 
porous properties of the catalysts can increase the contact area and also provide more channels for the efficient transportation of some substances, including $\mathrm{O}_{2}, \mathrm{H}_{2} \mathrm{O}, \mathrm{H}_{2} \mathrm{O}_{2}$, and other intermediates [27]. This favorable structure may play a pivotal function in improving the ORR activity of materials.

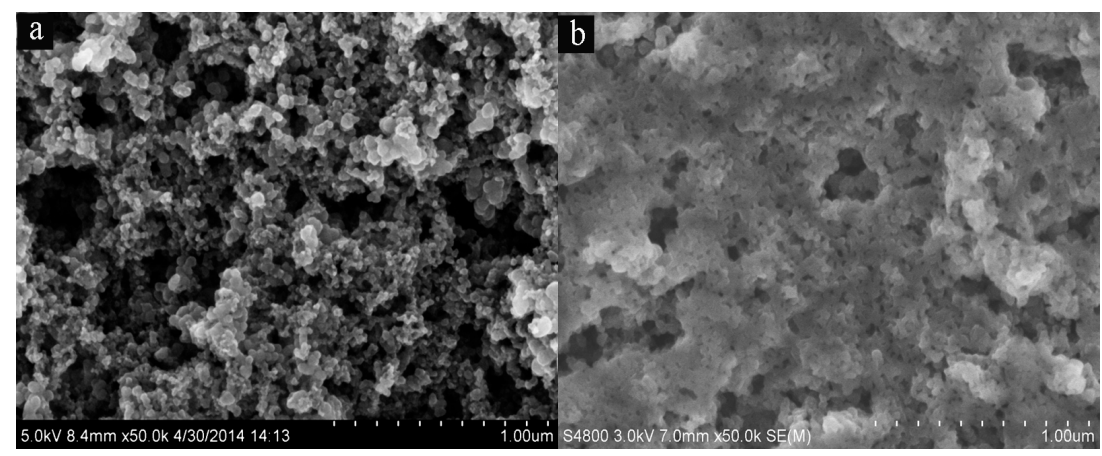

Figure 1. SEM images of carbon black (a) and Cu-SOCBP/C (b).

The surface areas and pore volumes of the samples including Vulcan XC-72 carbon and $\mathrm{Cu}$-SOCBP/C were determined by nitrogen sorption analysis [28]. The sorption isotherms of samples are shown in Figure 2. From this figure, a total surface area of $166.67 \mathrm{~m}^{2} / \mathrm{g}$, and a pore volume of $0.30 \mathrm{~cm}^{3} / \mathrm{g}$ was obtained for Vulcan XC-72 carbon, and the corresponding data for Cu-SOCBP/C were $70.46 \mathrm{~m}^{2} / \mathrm{g}$ and $0.21 \mathrm{~cm}^{3} / \mathrm{g}$, respectively. The decrease in both of the parameters of Cu-SOCBP/C compared to those of the carbon powder was another indication of the formation of $\mathrm{Cu}-\mathrm{SOCBP} / \mathrm{C}$.

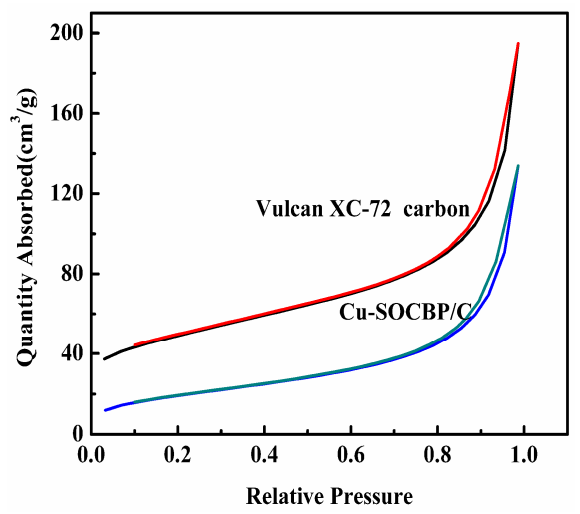

Figure 2. Nitrogen adsorption/desorption isotherms of Vulcan XC-72 and the Cu-SOCBP/C composite.

\subsection{XPS and Powder X-ray Diffraction of the Catalyst}

Chemical compositions and their valence states were analyzed via XPS measurements. For Cu-SOCBP, the N 1s spectrum has two obvious peaks. One is the main peak located at $399.7 \mathrm{eV}$ (Figure 3a), and the other is the acromion of the main peak at a higher binding energy of $401.8 \mathrm{eV}$. Obviously, the peak at $401.8 \mathrm{eV}$ corresponds to pyrrolic-N in the carbazole ring of the ligand, and the peak at $399.7 \mathrm{eV}$ is a definite indication of the presence of pyridinic- $\mathrm{N}$ in the composite (Figure 3a). The presence of two types of nitrogen elements was consistent with the structure of $\mathrm{Cu}-\mathrm{SOCBP}$. The binding energies of pyridinic-N found in this study were higher than those usually reported for pyridinic- $\mathrm{N}$, and this is an apparent indication of complexation between copper ions and pyridinic-N $[29,30]$. Furthermore, this also suggests the formation of the supramolecule metal complex, as indicated in Scheme 1.

To confirm the presence and form of the copper ions, the $\mathrm{Cu} 2 \mathrm{p}$ spectrum was recorded and is presented in Figure $3 b$; the spectrum clearly confirms the presence of copper ions on the surface of the 
$\mathrm{Cu}-\mathrm{SOCBP} / \mathrm{C}$ catalyst. There are two pairs of $\mathrm{Cu} 2 \mathrm{p}$ peaks; one pair of peaks is located at 935.0 and $932.4 \mathrm{eV}$ and represents the binding energy of $\mathrm{Cu} 2 \mathrm{p}_{3 / 2}$. The second pair of $\mathrm{Cu} 2 \mathrm{p}$ peaks is located at $952.3 \mathrm{eV}$ and $954.9 \mathrm{eV}$ and can be ascribed to the binding energy of $\mathrm{Cu} 2 \mathrm{p}_{1 / 2}$ [17]. The $\mathrm{Cu} 2 \mathrm{p}$ peaks at $935 \mathrm{eV}$ and $954.9 \mathrm{eV}$ and the satellite peak at $945 \mathrm{eV}$ were definitive evidence for the presence of the coordinated copper ion(II) (Scheme 1). Besides, the $\mathrm{Cu} 2 \mathrm{p}$ peaks at $932.4 \mathrm{eV}$ and $952.3 \mathrm{eV}$ suggested the presence of the copper ion(II) in $\mathrm{CuSO}_{4}$, which might be temporarily adsorbed on carbon materials [31].

As previously reported, pyridinic-N and its complex with transition metal ions (e.g., $\mathrm{Cu}-\mathrm{N}_{x}$ ) are the main active sites for ORR activity, and in particular, the formation of $\mathrm{Cu}-\mathrm{N}_{x}$ complexes can substantially enhance catalytic ORR activity [11]. The above XPS analyses confirm the formation of the Cu-SOCBP supramolecule complex, which contained large amount of $\mathrm{Cu}-\mathrm{N}_{x}$ moieties within the catalyst and made it possible for $\mathrm{Cu}-\mathrm{SOCBP} / \mathrm{C}$ to become an efficient oxygen reduction catalyst.
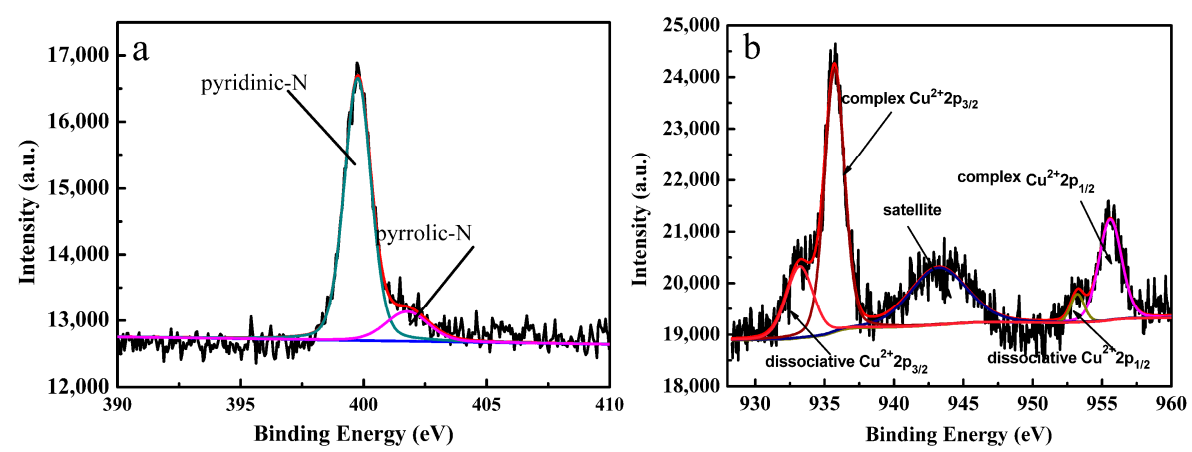

Figure 3. X-ray photoelectron spectroscopy (XPS) spectra of N 1s (a) and Cu 2p (b) for Cu-SOCBP/C.

The formation of the Cu-SOCBP/C composite was further verified by powder X-ray diffraction (XRD. Figure 4 shows the XRD spectra of the Vulcan XC-72 powder and Cu-SOCBP/C. Two broad XRD peaks centered at $24.9^{\circ}$ and $43.3^{\circ}$ were observed for the carbon powder, which could be attributed to the inter-plane (002) and inner-plane (110) reflections of graphitic carbon, respectively [32]. After the introduction of Cu-SOCBP additives, both the $002\left(2 \theta=24.7^{\circ}\right)$ and the $110\left(2 \theta=42.9^{\circ}\right)$ peaks shifted to slightly lower angles, suggesting a slightly larger d-spacing of the carbon powder. Also, the inner-plane (110) reflection of the composite became flatter compared with that of the net carbon powder, which indicated the enlarged amorphous property of the composite. Furthermore, a new XRD peak $\left(2 \theta=36.1^{\circ}\right)$ emerged for the $\mathrm{Cu}-\mathrm{SOCBP} / \mathrm{C}$ composite, which might be caused by the introduction of $\mathrm{Cu}-\mathrm{SOCBP}$ to the carbon powder [32].

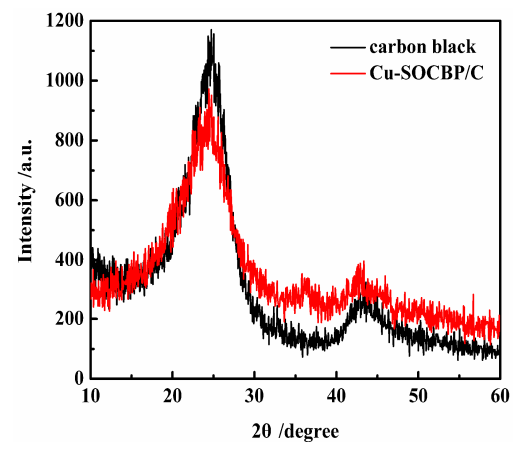

Figure 4. Powder X-ray diffraction (XRD) spectra of carbon black and Cu-SOCBP/C.

\subsection{Cyclic Voltammetry of the Catalyst}

$\mathrm{CV}$ was used to evaluate the electrocatalytic activity of Cu-SOCBP/C for ORR. The potential window used in the cyclic voltammogram was from $-0.19 \mathrm{~V}$ to $1.11 \mathrm{~V}$ (vs. RHE) for Cu-SOCBP/C and 
$0 \mathrm{~V}$ to $1.2 \mathrm{~V}$ for the commercial Pt/C catalyst. Figure 5a shows two CV curves of the Cu-SOCBP/C catalyst in a medium of $0.1 \mathrm{M} P B S(\mathrm{pH}=7)$; one saturated with $\mathrm{O}_{2}$, and one saturated with $\mathrm{N}_{2}$. The $\mathrm{CV}$ curve recorded in the $\mathrm{N}_{2}$ atmosphere shows a pair of irreversible redox peaks at $0.55 \mathrm{~V} / 0.50 \mathrm{~V}$, and these can be ascribed to the redox reaction process of $\mathrm{Cu}^{+} / \mathrm{Cu}^{2+}$; this further confirmed the immobilization of copper ions within the catalyst $[17,21]$. In contrast, when $\mathrm{N}_{2}$ was replaced by $\mathrm{O}_{2}$ as the bubbling gas, it was observed that both the oxidation current and reduction current increased substantially. In particular, the reduction current increased to $0.47 \mathrm{~mA}$, which is nearly six times greater than that measured in the $\mathrm{N}_{2}$-saturated electrolyte. By comparison, it is obvious that the increase in the reduction current was because of the reduction of oxygen catalyzed by the Cu-SOCBP/C-modified electrode. Thus, it is preliminarily concluded that Cu-SOCBP/C has electrocatalytic activity for ORR, and this is consistent with the $\mathrm{Cu}-\mathrm{N}_{x}$-enriched structure $[17,21]$.

To gain comprehensive insights into the catalytic activity of the $\mathrm{Cu}-\mathrm{SOCBP} / \mathrm{C}$ catalyst, $\mathrm{CV}$ measurements of the commercial $\mathrm{Pt} / \mathrm{C}$ catalyst were also taken in the PBS solution saturated with oxygen with a potential window from $0.01 \mathrm{~V}$ to $1.21 \mathrm{~V}$ (vs. RHE). As shown in Figure $5 \mathrm{~b}$, the reduction peak potential of $\mathrm{Cu}-\mathrm{SOCBP} / \mathrm{C}$ is somewhat more negative than that of $\mathrm{Pt} / \mathrm{C}$, whereas the maximum reduction current was 1.25 times greater than that of $\mathrm{Pt} / \mathrm{C}$. To further verify the catalytic activity of Cu-SOCBP/C, the ORR activity of the carbon powder was also tested in the same way (Figure S1, see Supplementary Materials). The reduction peak and reduction current was $0.30 \mathrm{~V}$ and $0.20 \mathrm{~mA}$, respectively, for the net carbon powder, which verified the improvement in ORR activity by the formation of the Cu-SOCBP/C composite.
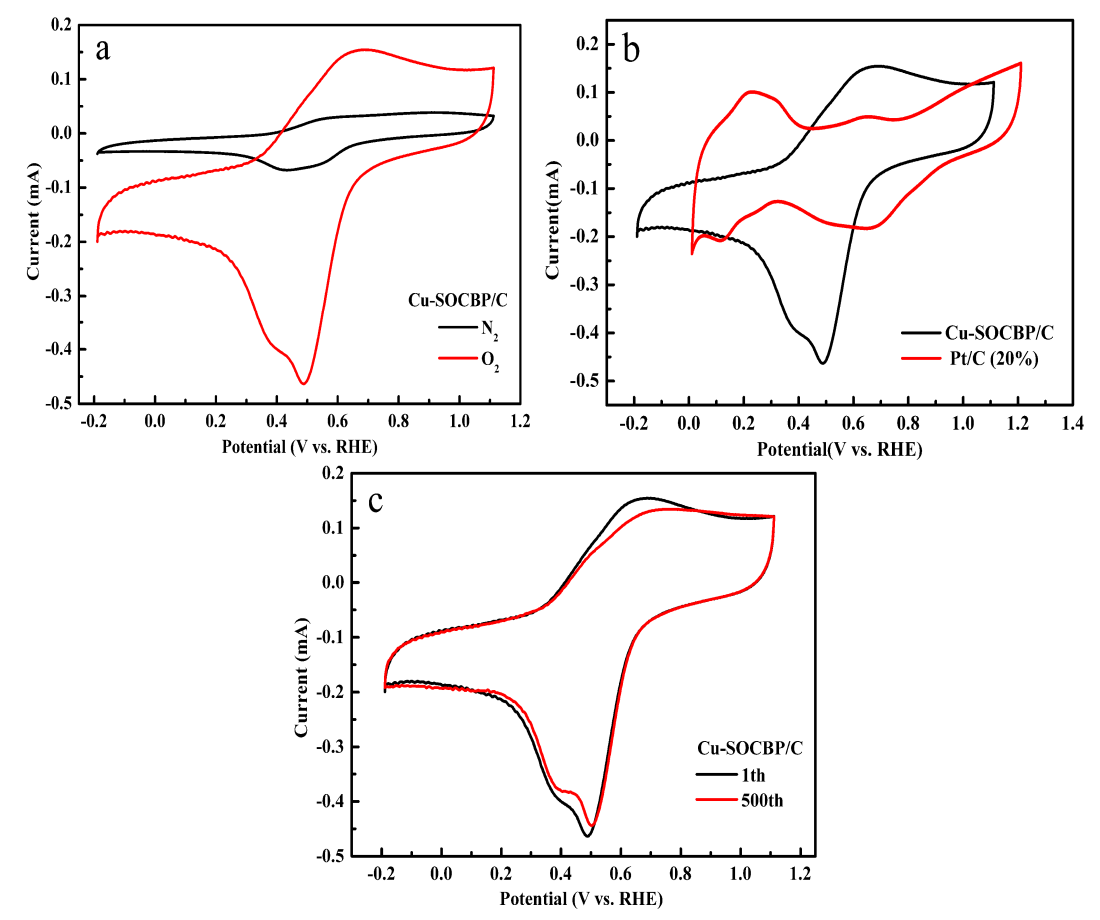

Figure 5. Cyclic voltammetry (CV) of Cu-SOCBP/C in phosphate buffer solution (PBS) saturated once with $\mathrm{N}_{2}$ and once with $\mathrm{O}_{2}(\mathbf{a}) ; \mathrm{CV}$ of $\mathrm{Cu}-\mathrm{SOCBP} / \mathrm{C}$ and Pt/C in PBS saturated with $\mathrm{O}_{2}(\mathbf{b})$; and $\mathrm{CV}$ of $\mathrm{Cu}-\mathrm{SOCBP} / \mathrm{C}$ in PBS saturated with $\mathrm{O}_{2}$ (c). Scan rate: $100 \mathrm{mV} / \mathrm{s}$.

Repeated CV measurements were taken for over 500 cycles between $-0.19 \mathrm{~V}$ to $1.11 \mathrm{~V}$ in an oxygen-saturated electrolyte to study the stability of Cu-SOCBP/C. After 500 cycles, a slight decrease in the reduction current (less than $2.0 \%$ ) and a positive shift in the reduction potential were observed (in Figure 5c), indicating that the Cu-SOCBP/C catalyst has good electrochemical stability. The data indicates that $\mathrm{Cu}-\mathrm{SOCBP} / \mathrm{C}$ has roughly the same power of ORR activity as the $\mathrm{Pt} / \mathrm{C}$ catalyst. 


\subsection{Linear Sweep Voltammetry}

The electron transfer number $(n)$ involved in the ORR process is a pivotal parameter in determining the catalytic activities of ORR materials; $n$ can be obtained via routine electrochemical measurements. For this purpose, LSV curves of the catalysts (including Cu-SOCBP/C and $\mathrm{Pt} / \mathrm{C}$ ) were record on an rotating disk electrode (RDE) electrode at different rotating rates from $400 \mathrm{rpm}$ to $1600 \mathrm{rpm}$. Figure 6a shows that, at different rotating rates, there were only tiny currents in the PBS that was saturated with $\mathrm{N}_{2}$. However, the current densities increased rapidly when the testing buffer was saturated with oxygen, and this was apparently caused by the catalytic reduction of oxygen in the buffer solution (Figure 6b).

The RDE curves of the catalysts had roughly the same shape, and can be divided into two obvious different regions: one is the kinetic/diffusion current region, and the other is the diffusion control region. It should be noted that different potential windows were selected for each of the catalysts due to their expected different onset reduction potentials $\left(E_{\text {onset }}\right)$. For the Cu-SOCBP/C catalyst, the kinetic/diffusion current region was observed from $0.2 \mathrm{~V}$ to $0.62 \mathrm{~V}$, and in this region, the reaction rates were controlled simultaneously via charge transfer and the mass transfer rate. At the same time, the diffusion control region of Cu-SOCBP/C was found under $0.2 \mathrm{~V}$; in this region, the reaction rate was only controlled via the mass transfer rate, and the linear polarization curves have well-defined plateaus with a constant maximum current value [33].
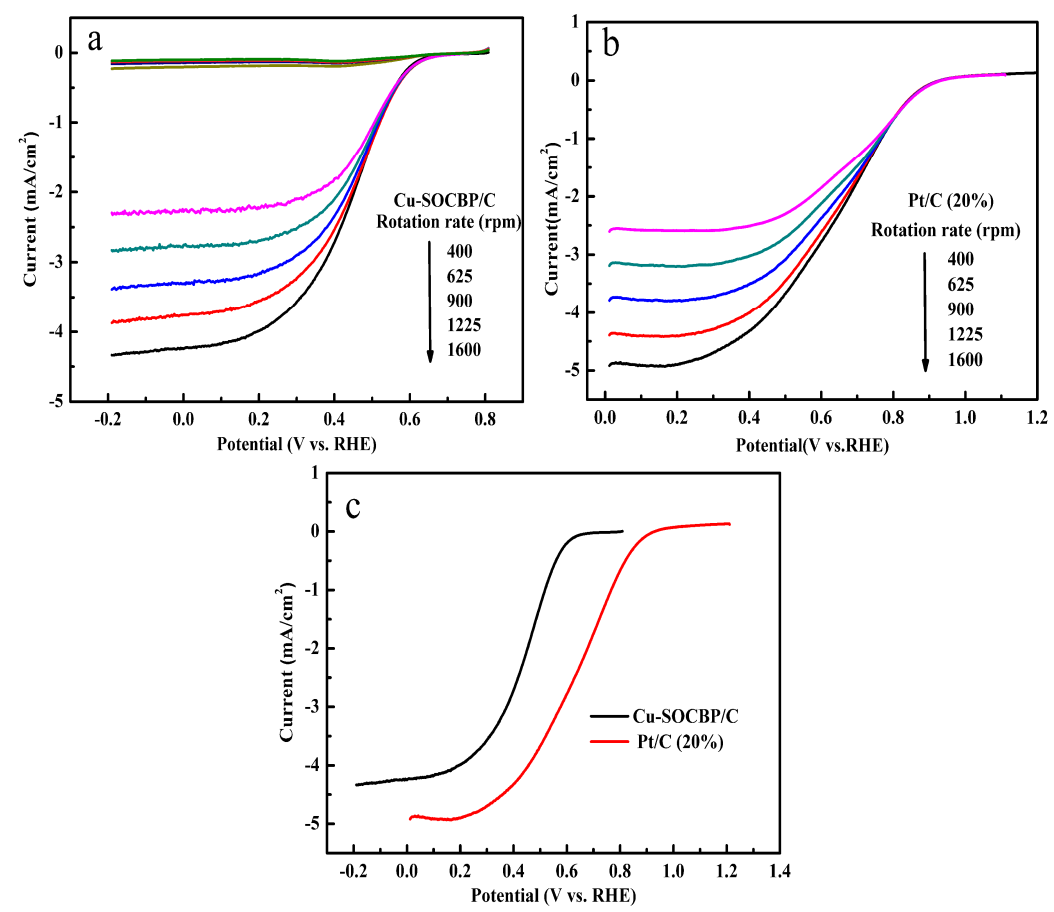

Figure 6. (a) Polarization curves of Cu-SOCBP/C obtained at different rotating rates using $\mathrm{N}_{2}$-saturated electrolyte (upper part) or $\mathrm{O}_{2}$-saturated electrolyte (lower part). (b) Polarization curves of $\mathrm{Pt} / \mathrm{C}$ with a dependence of current magnitude on rotation rate. (c) Polarization curves of $\mathrm{Cu}$-SOCBP/C and $\mathrm{Pt} / \mathrm{C}$ at a rotating rate of $1600 \mathrm{rpm}$.

The maximum limiting currents of the catalysts increased with an increase in the rotating speeds of the RDE measurement, and this suggests that, along with an increase in the rotating speed, the amount of oxygen diffusion to the surface of the electrode increased, which causes more oxygen reduction at the cathode. In addition, the behaviors of the polarization curves at different rotating rates are similar, and the $E_{\text {onset }}$ values can be obtained from the crossover point of the tangent line of the mixing zone and the horizontal line; this point has a constant value of $0.62 \mathrm{~V}$ vs. RHE for the 
$\mathrm{Cu}-\mathrm{SOCBP} / \mathrm{C}$ catalyst [17]. For comparative purposes, the RDE measurements of $\mathrm{Pt} / \mathrm{C}$ were also taken with a potential window from $0 \mathrm{~V}$ to $1.2 \mathrm{~V}$ vs. RHE in the same test buffer as that of Cu-SOCBP/C. As shown in Figure 6b, the kinetic/diffusion current region of Pt/C occurred at $0.87 \mathrm{~V}$ to $0.31 \mathrm{~V}$, and the diffusion control region was observed below $0.31 \mathrm{~V}$. In addition, $\mathrm{Pt} / \mathrm{C}$ has an onset reduction potential of $0.87 \mathrm{~V}$, which is higher than that of the Cu-SOCBP/C catalyst. For comparison, Figure $6 \mathrm{c}$ shows the RDE curves of the two catalysts at $1600 \mathrm{rpm}$; the onset reduction potentials and limiting-current densities were $0.62 \mathrm{~V}$ and $4.3 \mathrm{~mA} \mathrm{~cm}{ }^{-2}$, respectively, for $\mathrm{Cu}-\mathrm{SOCBP} / \mathrm{C}$ and $0.87 \mathrm{~V}$ and $5 \mathrm{~mA} \mathrm{~cm}{ }^{-2}$, respectively, for $\mathrm{Pt} / \mathrm{C}$. The RDE curves of the Vulcan XC-72-modified electrode were also determined, and exhibited a much lower $E_{\text {onset }}(0.43 \mathrm{~V})$, as well as much lower limiting current densities compared to those of the Cu-SOCBP/C catalyst (Figure S2).

The data indicates that the catalytic activity of Cu-SOCBP/C was a little poorer than that of the $\mathrm{Pt} / \mathrm{C}$ catalyst. Nevertheless, considering the low-cost advantages of $\mathrm{Cu}-\mathrm{SOCBP} / \mathrm{C}$ catalysts, it might still be a promising cathodic catalyst in some fuel cells, such as MFCs.

To obtain the value of $n$ involved in ORR activity for the Cu-SOCBP/C catalyst, the data acquired from RDE measurements were used to construct the Koutecky-Levich (K-L) equations [17]:

$$
\begin{gathered}
1 / i=1 / i_{k}+1 / B \omega^{1 / 2} \\
B=0.62 n F C_{\mathrm{O}_{2}} D_{\mathrm{O}_{2}}^{2 / 3} v^{-1 / 6}
\end{gathered}
$$

In Equations (1) and (2), the physical meaning of the related parameters (including $i, i_{k}, \omega, n, F$, and $v$ ) is available in the previously published literature [23].

Using the slope $(1 / B)$ of the plot of $1 / i$ vs. $\omega^{-1 / 2}$ (Figure 7), the $n$ value can be calculated using Equation (2). The fitting equations and the values of $\mathrm{R}^{2}$ in the K-L plots of the catalysts are shown in Table S1 (Supplementary Materials). For the Cu-SOCBP/C catalyst (Figure 7a), the plots of $1 / i$ vs. $\omega^{-1 / 2}$ at different potentials were all linear and parallel, and this reveals that the $n$ values per oxygen consumed in the ORR reactions were the same. Specifically, the $n$ values were calculated to be $4,3.7$, 3.6, and 3.6 at $0.41 \mathrm{~V}, 0.36 \mathrm{~V}, 0.31 \mathrm{~V}$, and $0.26 \mathrm{~V}$, respectively, for Cu-SOCBP with a rotation rate fixed at $1600 \mathrm{rpm}$. For the Pt/C catalyst, the $n$ values were calculated to be 4.0, 4.0, and 3.8 at potentials of $0.2 \mathrm{~V}$, $0.3 \mathrm{~V}$, and $0.4 \mathrm{~V}$, respectively (Figure $7 \mathrm{~b}$ ). The data indicated that the Cu-SOCBP/C catalyst plays a role as an electrocatalyst via a four-electron dominant transfer pathway, and this was comparable to that of $\mathrm{Pt} / \mathrm{C}$, except that the $E_{\text {onset }}$ of $\mathrm{Cu}-\mathrm{SOCBP}$ was somewhat lower than that of $\mathrm{Pt} / \mathrm{C}$. The $n$ values for Vulcan XC-72 were calculated to be 1.67-2.33, which was much lower than that of the Cu-SOCBP/C and $\mathrm{Pt} / \mathrm{C}$ catalysts (Figure S3).
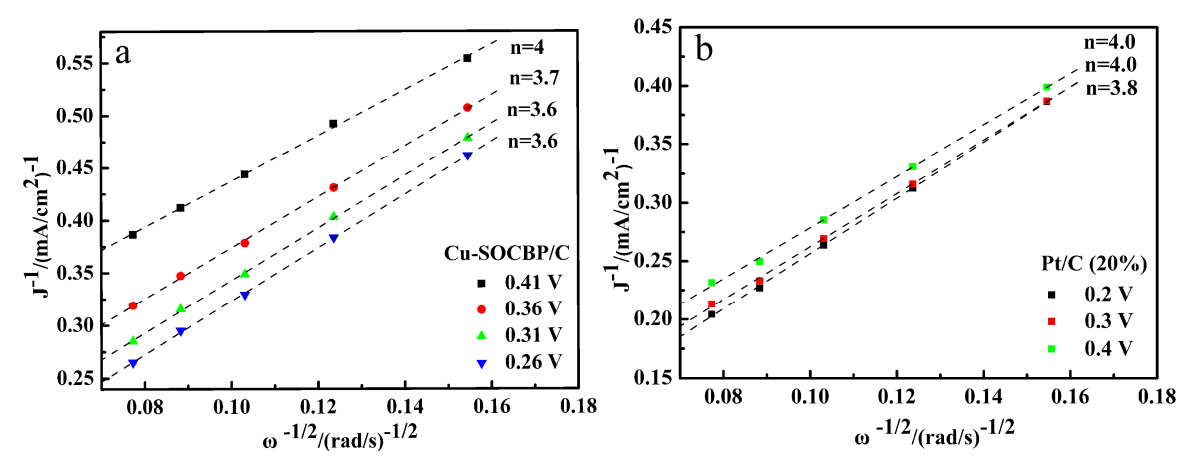

Figure 7. K-L plots at potentials of $0.41 \mathrm{~V}, 0.36 \mathrm{~V}, 0.31 \mathrm{~V}$, and $0.26 \mathrm{~V}$ for Cu-SOCBP/C (a); and those for $\mathrm{Pt} / \mathrm{C}$ at potentials of $0.2 \mathrm{~V}, 0.3 \mathrm{~V}$, and $0.4 \mathrm{~V}(\mathbf{b})$.

It is known that the direct transformation of oxygen to water (involving four electrons) is superior to the process of hydrogen peroxide formation (involving two electrons) because the former has higher oxygen utilization efficiency than the latter. Additionally, the $\mathrm{H}_{2} \mathrm{O}_{2}$ produced in the latter process has 
a corrosive effect on fuel cells. Thus, the oxygen reduction process of Cu-SOCBP is preferred because its $n$ values approach 4 .

\subsection{RRDE Measurements of the Catalysts}

RRDE measurements were also taken in the electrolyte using a series of rotating rates to gain more insight into the precise ORR pathway of the Cu-SOCBP composite as well as the production and further reduction of $\mathrm{H}_{2} \mathrm{O}_{2}$ as an intermediate. The disk potential ranged from 0.81 to $-0.4 \mathrm{~V}$ (vs. RHE), and the ring potential was set at $0.6 \mathrm{~V}$ (vs. $\mathrm{Ag} / \mathrm{AgCl}$ /saturated $\mathrm{KCl}$ ) to ensure that all of the $\mathrm{H}_{2} \mathrm{O}_{2}$ produced in the electrocatalyzed ORR process was oxidized to water at the ring electrode. RRDE voltammetry curves are shown in Figure 8a, and the upper part of the figure shows currents of the ring electrode, while the lower part of the figure shows the disk current. With an increase in the rotating speeds, the currents on both the ring electrode and the disk electrode increased simultaneously, which means that $\mathrm{H}_{2} \mathrm{O}_{2}$ was generated in the ORR process and was detected on the ring electrode. The data from the RRDE experiment were then used for a further explanation of the ORR pathways. First, the electron transfer numbers (ETN) values and percentages of $\mathrm{H}_{2} \mathrm{O}_{2}$ production were calculated using the following equations [29]:

$$
\begin{gathered}
n=\frac{4 I_{d}}{I_{d}+\left(I_{r} / N\right)} \\
\% \mathrm{H}_{2} \mathrm{O}_{2}=\frac{200 I_{r} / N}{I_{d}+\left(I_{r} / N\right)}
\end{gathered}
$$

In Equations (3) and (4), $N$ is the collection efficiency (43\%) of $\mathrm{H}_{2} \mathrm{O}_{2}, I_{r}$ is the ring current, and $I_{d}$ is the disk current. Using the calculation results, the yields (\%) of $\mathrm{H}_{2} \mathrm{O}_{2}$ for $\mathrm{Cu}-\mathrm{SOCBP} / \mathrm{C}$ were lower than $10.2 \%$, and the value of $n$ was 3.8 over the potential range of $0.01 \mathrm{~V}$ to $0.31 \mathrm{~V}$ (Figure $8 \mathrm{~b}, \mathrm{c}$ ). The $n$ values calculated from the RRDE data were consistent with those acquired from the RDE measurements. Thus, it was finally confirmed that $\mathrm{Cu}-\mathrm{SOCBP} / \mathrm{C}$ catalyzed a four-electron prominent transfer process with low $\mathrm{H}_{2} \mathrm{O}_{2}$ yields and high ETN values that were approximately 4. For comparison, the RRDE measurements of $\mathrm{Pt} / \mathrm{C}$ were also carried out. According to the data from the RRDE curves (Figure S4a), the average yield (\%) of $\mathrm{H}_{2} \mathrm{O}_{2}$ was $1.6 \%$, and the calculated electron-transfer number was 4 (Figure $\mathrm{S} 4 \mathrm{~b}, \mathrm{c}$ ).
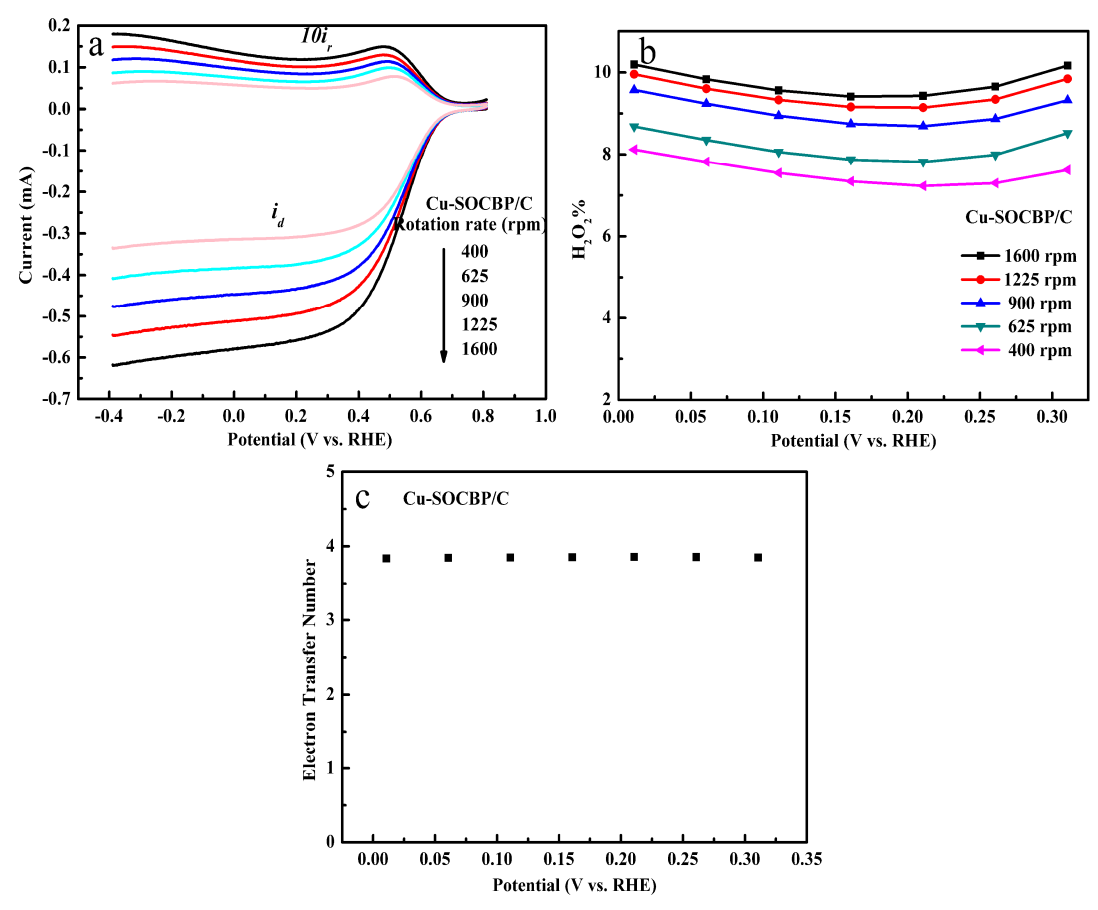

Figure 8. RRDE curves (a); peroxide yields (b); and $n$ values (c) of Cu-SOCBP/C. 
Parameters of other $\mathrm{M}-\mathrm{N}_{x}$-containing catalysts are also included in Table 1, including the onset reduction potential $\left(E_{\text {onset }}, \mathrm{V}\right)$, the half-wave potential $\left(E_{1 / 2}, \mathrm{~V}\right)$, electron transfer number (ETN), and $\mathrm{H}_{2} \mathrm{O}_{2}$ yields (\%); the parameters for the catalyst reported in this study were also included $[15,16,18,34-36]$. In making a comprehensive comparison of the data in Table 1, it can be concluded that the ORR ability of Cu-SOCBP/C is equivalent to or better than most of the reported catalysts. It must be noted that the optimum operating medium for the catalyst in this study is a neutral aqueous solution; it is not an acidic or alkaline medium, and this limits its application as catalysts in proton exchange membrane fuel cells or alkaline membrane fuel cells. The catalyst reported in this study can be used in MFCs, which are new fuel cells being used in industrial implementations and are operated in neutral aqueous solution.

Table 1. ORR abilities of some $\mathrm{M}-\mathrm{N}_{x}$-containing non-noble catalysts reported in recent years.

\begin{tabular}{|c|c|c|c|c|c|c|c|}
\hline Catalyst & $\begin{array}{l}E_{\text {onset }} \\
\text { (V) }\end{array}$ & $\begin{array}{l}E_{1 / 2} \\
(\mathrm{~V})\end{array}$ & ETN & $\begin{array}{c}\text { Average } \\
\mathrm{H}_{2} \mathrm{O}_{2}(\%)\end{array}$ & $\begin{array}{l}\text { Electrolyte } \\
\text { Solution }\end{array}$ & $\begin{array}{l}\text { Referance } \\
\text { Electrode }\end{array}$ & Ref. \\
\hline Cu-SOCBP/C & 0.62 & 0.44 & 3.8 & $9 \%$ & PBS (pH = 7) & RHE & This study \\
\hline $\mathrm{Pt} / \mathrm{C}(20 \%)$ & 0.90 & 0.63 & 4.0 & $1.6 \%$ & PBS ( $\mathrm{pH}=7)$ & RHE & This study \\
\hline CoTHPP/PSS-rGO & - & -0.22 & 4.0 & - & $0.1 \mathrm{M} \mathrm{KOH}$ & SCE & [15] \\
\hline Co-OBA/C & -0.197 & - & 3.75 & - & $0.1 \mathrm{M} \mathrm{KOH}$ & $\mathrm{Ag} / \mathrm{AgCl}$ & [37] \\
\hline POT-CO-OMC & -0.3 & - & 3.82 & - & $0.1 \mathrm{M} \mathrm{KOH}$ & $\mathrm{Ag} / \mathrm{AgCl}$ & [38] \\
\hline bi-FePc/GNS & 0.12 & & 3.7 & - & $0.5 \mathrm{M} \mathrm{H}_{2} \mathrm{SO}_{4}$ & $\mathrm{Hg} / \mathrm{Hg}_{2} \mathrm{SO}_{4}$ & [39] \\
\hline Phen-Co/rGO & - & -0.25 & 2.4 & - & $0.1 \mathrm{M} \mathrm{NaOH}$ & $\mathrm{Ag} / \mathrm{AgCl}$ & [18] \\
\hline Corrole-Co/MWCNT & 0.75 & 0.40 & 4.0 & - & $0.5 \mathrm{M} \mathrm{H}_{2} \mathrm{SO}_{4}$ & NHE & [16] \\
\hline
\end{tabular}

\subsection{Specific Reduction Pathway of $\mathrm{Cu}$-SOCBP/C}

Although the above data provide helpful information on ORR kinetics, specific insights into more detailed oxygen reduction routes are still needed. For example, the four-electron transfer process has two possible transfer pathways: (1) a "step-by-step" four-electron pathway $\left(k_{2}=k_{3}, k_{1}=0\right)$, and (2) a direct four-electron pathway ( $\left.k_{1}>>k_{2}, k_{3}=0\right)$. The mechanisms proposed by Damjanovic et al. are shown in Figure $9 ; k_{1}, k_{2}$, and $k_{3}$ are the rate constants for each step [37].

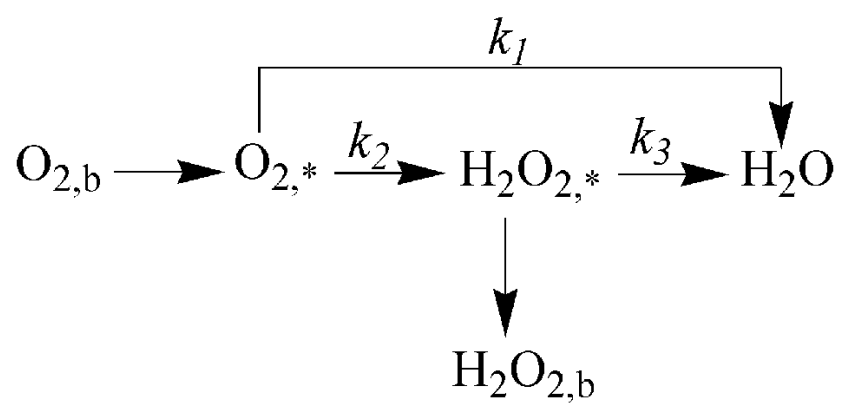

Figure 9. Possible routes for oxygen reduction. Footnotes $b$ and * indicate reactions in the bulk solution and reaction on the electrode surface, respectively.

The pathway model for a direct four-electron transfer process can be expressed as Equation (5), and a "step-by-step" four-electron pathway can be expressed as Equations (6) and (7).

$$
\begin{gathered}
\mathrm{O}_{2}+4 \mathrm{H}^{+}+4 \mathrm{e}^{-} \stackrel{k_{1}}{\rightarrow} 2 \mathrm{H}_{2} \mathrm{O} \\
\mathrm{O}_{2}+2 \mathrm{H}^{+}+2 \mathrm{e}^{-} \stackrel{k_{2}}{\rightarrow} \mathrm{H}_{2} \mathrm{O}_{2} \\
\mathrm{H}_{2} \mathrm{O}_{2}+2 \mathrm{H}^{+}+2 \mathrm{e}^{-} \stackrel{k_{3}}{\rightarrow} 2 \mathrm{H}_{2} \mathrm{O}
\end{gathered}
$$


RRDE data can also be used to calculate the rate constants $k_{1}, k_{2}$, and $k_{3}$ according to Equations (8)-(10) to identify the exact mechanism of ORR for Cu-SOCBP/C [37,38].

$$
\begin{gathered}
k_{1}=S_{2} Z_{\mathrm{O}_{2}} \frac{I_{1} N-1}{I_{1} N+1} \\
k_{2}=\frac{2 Z_{\mathrm{O}_{2}} S_{2}}{I_{1} N+1} \\
k_{3}=\frac{Z_{\mathrm{H}_{2} \mathrm{O}_{2}} N S_{1}}{I_{1} N+1}
\end{gathered}
$$

In Equations (8)-(10), $\mathrm{Z}_{\mathrm{H}_{2} \mathrm{O}_{2}}=0.62 D_{\mathrm{H}_{2} \mathrm{O}_{2}}^{2 / 3} v^{-1 / 6}$ and $\mathrm{Z}_{\mathrm{O}_{2}}=0.62 D_{\mathrm{O}_{2}}^{2 / 3} v^{-1 / 6}$, where $D_{\mathrm{H}_{2} \mathrm{O}_{2}}$ and $D_{\mathrm{O}_{2}}$ are diffusion coefficients of $\mathrm{H}_{2} \mathrm{O}_{2}$ and $\mathrm{O}_{2}$, respectively, in PBS solution. $I_{1}$ and $S_{1}$ are, respectively, the intercept and slope from the plot of $I_{d} / I_{r}$ vs. $\omega^{-1 / 2}$, and $S_{2}$ is the slope from the plot of $I_{d l} /\left(I_{d l}-I_{d}\right)$ vs. $\omega^{-1 / 2} . I_{d l}$ is the disk-limiting current $[37,38]$.

The values of $k_{1}, k_{2}$, and $k_{3}$ are shown in Figure 10a. It can be seen that $k_{1}>>k_{2} \sim k_{3}$, and this suggests that oxygen was mainly reduced to $\mathrm{H}_{2} \mathrm{O}$ via a direct mode with a fast reaction rate. It can also be found from Figure 10a that the value of $k_{2}$ was comparable to that of $k_{3}$, and this indicates that a small portion of oxygen was reduced to $\mathrm{H}_{2} \mathrm{O}_{2}$ as an intermediate, and then $\mathrm{H}_{2} \mathrm{O}_{2}$ was reduced to $\mathrm{H}_{2} \mathrm{O}$ at the same rate. It is noted that the value of $k_{2}$ is slightly larger than that of $k_{3}$, and this indicates that a small amount of $\mathrm{H}_{2} \mathrm{O}_{2}$ is produced in the electrocatalysis of oxygen by the Cu-SOCBP/C catalyst (Figure 8b).

These results indicate that $\mathrm{Cu}-\mathrm{SOCBP} / \mathrm{C}$ catalyzed the ORR process mainly via a four-electron transfer process consisting of a direct route (which was primary) and a "step-by-step" route (which was auxiliary), both of which were four-electron processes. In addition, variations in the rate constant ratio $\left(k_{1} / k_{2}\right)$ were also investigated, along with the potential difference posed on the catalyst-modified electrode. As shown in Figure $10 \mathrm{~b}$, the ratio of $k_{1} / k_{2}$ remained at an approximately constant value, which was around 5 for the potential range of -0.1 to $0.5 \mathrm{~V}$. Obviously, the direct four-electron transfer pathway is the main ORR process for the $\mathrm{Cu}-\mathrm{SOCBP} / \mathrm{C}$ catalyst.
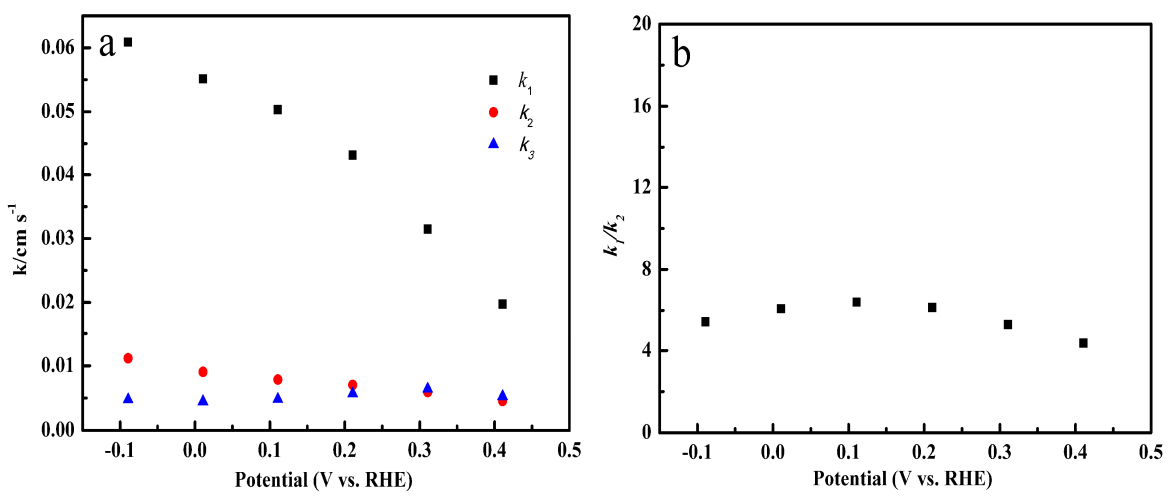

Figure 10. Values of $k_{1}, k_{2}$, and $k_{3}$ of the ORR pathway model for $\mathrm{Cu}-\mathrm{SOCBP} / \mathrm{C}(\mathbf{a})$; and the ratios of $k_{1} / k_{2}(\mathbf{b})$.

\section{Experimental}

\subsection{Materials}

9-octyl-2,7-bis(4,4,5,5-tetramethyl-1,3,2-dioxaborolan-2-yl)-9H-carbazole (M1), 5-bromo-1,10phenanthroline (M2), toluene, $\mathrm{K}_{2} \mathrm{CO}_{3}, \mathrm{NaH}_{2} \mathrm{PO}_{4} \cdot 2 \mathrm{H}_{2} \mathrm{O}$, tetrabutylammonium fluoride $\left(\mathrm{NBu}_{4} \mathrm{~F}\right)$, $\mathrm{Pd}\left[\mathrm{P}\left(\mathrm{C}_{5} \mathrm{H}_{5}\right)_{3}\right]_{4}, \mathrm{Na}_{2} \mathrm{HPO}_{4} \cdot 12 \mathrm{H}_{2} \mathrm{O}, \mathrm{Cu}\left(\mathrm{ClO}_{4}\right)_{2} \cdot 6 \mathrm{H}_{2} \mathrm{O}$, and isopropanol were all analytical reagent (AR) grade and were obtained from Shanghai Aladdin Biochemical Technology Co., Ltd. (Shanghai, China) 
$\mathrm{Pt} / \mathrm{C}$ (20\% Pt content) and nafion (5\% content) were obtained from Shanghai Geshi Energy Technology Co., Ltd. (Shanghai, China), and ultrapure water was used without any disposal. Pure grade $\mathrm{O}_{2}$ and $\mathrm{N}_{2}$ were used to saturate the electrode test solutions.

\subsection{Synthesis of OCBP and $\mathrm{Cu}$-SOCBP}

M1 (2.034 g, $4 \mathrm{mM}), \mathrm{M} 2(1.950 \mathrm{~g}, 8 \mathrm{mM}), \mathrm{Pd}\left[\mathrm{P}\left(\mathrm{C}_{5} \mathrm{H}_{5}\right)_{3}\right]_{4}(0.37 \mathrm{~g}, 0.32 \mathrm{mM})$, and $\mathrm{NBu}_{4} \mathrm{~F}(0.015 \mathrm{~g})$ were added to a mixture medium consisting of toluene $(90 \mathrm{~mL})$ and $\mathrm{Na}_{2} \mathrm{CO}_{3}(60 \mathrm{~mL}, 2 \mathrm{M})$, which were combined in a round-bottom flask. This flask was maintained at $120^{\circ} \mathrm{C}$ under an argon atmosphere and stirred magnetically. The solvent and water were distilled under vacuum to obtain the solid crude product. The crude product was redissolved in chloroform and rinsed with water three times [39]. Excess solvents were removed via distillation to concentrate the organic phase, which was then subjected to silica gel column chromatography, and the solvent mixture of dichloromethane $/ n$-hexane $(2: 1, v / v)$ was used as the elution solvent. Finally, the product was obtained as a white solid (OCBP) with a yield of $65 \%$. The ${ }^{1} \mathrm{H}$ nuclear magnetic resonance $\left({ }^{1} \mathrm{H} \mathrm{NMR}\right)\left(400 \mathrm{MHz}, \mathrm{cdcl}_{3}\right)$ and ${ }^{13} \mathrm{C} \mathrm{NMR}$ $\left(101 \mathrm{MHz}, \mathrm{cdcl}_{3}\right)$ spectra of OCBP are shown in Figure 11.

${ }^{1} \mathrm{H}$ NMR $\left(400 \mathrm{MHz}, \mathrm{cdcl}_{3}\right) \delta 9.24(\mathrm{dt}, J=4.1,1.5 \mathrm{~Hz}, 4 \mathrm{H}), 8.43(\mathrm{dd}, J=8.4,1.6 \mathrm{~Hz}, 1 \mathrm{H}), 8.38-8.29$ $(\mathrm{m}, 1 \mathrm{H}), 7.91(\mathrm{~s}, 2 \mathrm{H}), 7.69(\mathrm{dd}, J=8.0,4.3 \mathrm{~Hz}, 2 \mathrm{H}), 7.61(\mathrm{dd}, J=8.4,4.2 \mathrm{~Hz}, 4 \mathrm{H}), 7.46(\mathrm{dd}, J=7.9,1.2 \mathrm{~Hz}$, $2 \mathrm{H}), 4.39(\mathrm{t}, J=7.0 \mathrm{~Hz}, 2 \mathrm{H}), 1.94(\mathrm{dd}, J=13.3,5.9 \mathrm{~Hz}, 4 \mathrm{H}), 1.48-1.36(\mathrm{~m}, 1 \mathrm{H}), 1.34-1.11(\mathrm{~m}, 2 \mathrm{H}), 0.78$ $(\mathrm{t}, J=6.8 \mathrm{~Hz}, 3 \mathrm{H})$.

${ }^{13} \mathrm{C} \mathrm{NMR}\left(101 \mathrm{MHz}, \mathrm{cdcl}_{3}\right) \delta 150.12(\mathrm{~d}, J=18.2 \mathrm{~Hz}), 146.36$ (s), 145.69 (s), 141.00 (s), 139.64 (s), 136.70 (s), $135.93(\mathrm{~s}), 134.77(\mathrm{~s}), 128.26(\mathrm{~s}), 128.05(\mathrm{~s}), 126.69(\mathrm{~s}), 123.37(\mathrm{~s}), 122.80(\mathrm{~s}), 122.17(\mathrm{~s}), 121.37(\mathrm{~s}), 120.46(\mathrm{~s})$, $110.26(\mathrm{~s}), 77.34(\mathrm{~s}), 77.02(\mathrm{~s}), 76.70(\mathrm{~s}), 43.26(\mathrm{~s}), 31.64(\mathrm{~s}), 29.43-28.77(\mathrm{~m}), 27.34(\mathrm{~s}), 22.50(\mathrm{~s}), 13.96(\mathrm{~s})$.
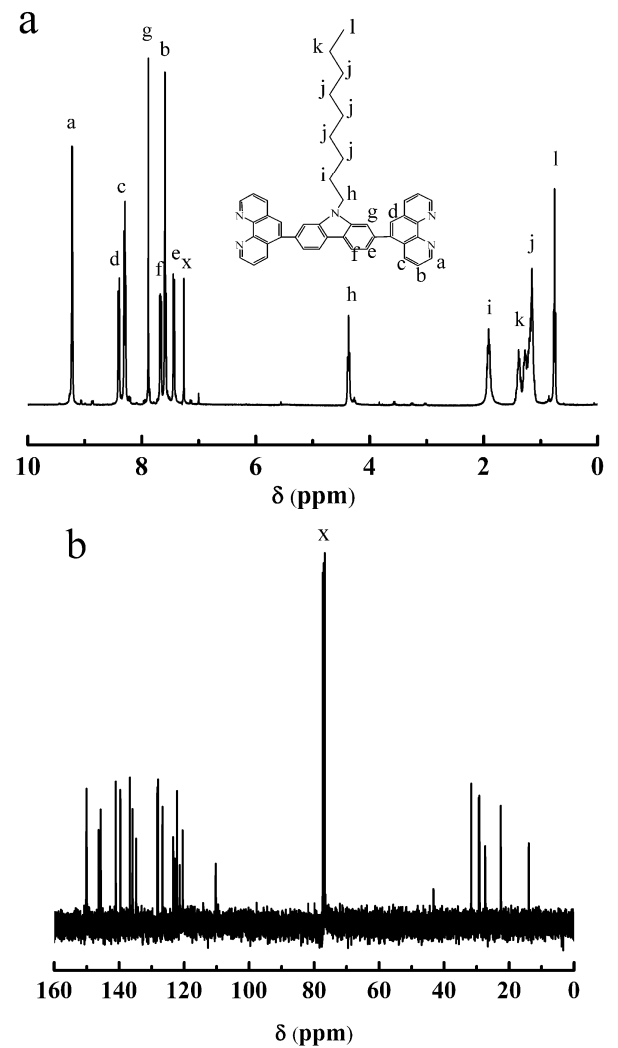

Figure 11. (a) ${ }^{1} \mathrm{H}$ NMR spectrum of 5,5'-(9-octyl-9H-carbazole-2,7-diyl)bis(1,10-phenanthroline) (OCBP) in $\mathrm{CDCl}_{3}$. Solvent peak $(x)$ is at $7.26 \mathrm{ppm}$. (b) ${ }^{13} \mathrm{C}$ NMR spectrum of monomer OCBP. Solvent peak $(x)$ is at $\delta=77.3 \mathrm{ppm}$. 
Also, Figure 12 shows the IR spectrum of OCBP. Assignment of the vibrational bands is as follows [40]: the peak at $3030 \mathrm{~cm}^{-1}$ corresponds to aromatic $\mathrm{C}-\mathrm{H}$ stretching, and the peaks between 2922 and $2851 \mathrm{~cm}^{-1}$ correspond to $\mathrm{C}-\mathrm{H}$ stretching of aliphatic side chains. Bands at $1596-1478 \mathrm{~cm}^{-1}$ and $1325 \mathrm{~cm}^{-1}$ are ascribed to the stretching vibrations of the $\mathrm{C}=\mathrm{N}$ bond (phenanthroline ring) and the $\mathrm{C}-\mathrm{N}$ bond (carbazole ring), respectively, and this is direct evidence for the linkage of the phenanthroline and carbazole ring. The bands in the region of $1478-1419 \mathrm{~cm}^{-1}$ are assigned to the $\mathrm{C}=\mathrm{C}$ skeleton vibration of the benzene ring. In addition, the peak at $1325 \mathrm{~cm}^{-1}$ corresponds to the stretching vibration of the $\mathrm{C}-\mathrm{N}$ bond in the phen ring, and the strong peak at $741 \mathrm{~cm}^{-1}$ corresponds to the out-of-plane bending vibration of the $\mathrm{C}-\mathrm{H}$ bond on the phen ring. The peak at $805 \mathrm{~cm}^{-1}$ is attributed to the out-of-plane bending vibration of the adjacent $\mathrm{C}-\mathrm{H}$ hydrogen atoms on the carbazole ring. In all, the data of the Infrared spectroscopy (IR) further confirm the successful synthesis of the desired OCBP compound.

To prepare Cu-SOCBP, the monomer OCBP $(3.8148 \mathrm{mg}, 0.006 \mathrm{mmol})$ was dissolved in $1 \mathrm{~mL}$ of acetonitrile under a nitrogen atmosphere. Copper(II) perchlorate hexahydrate $(2.22 \mathrm{mg}, 0.006 \mathrm{mmol})$ was then dissolved in $1 \mathrm{~mL}$ of acetonitrile and added dropwise into the above OCBP solution. The resulting green solution was the solution of Cu-SOCBP. The weight-average molecular weight of $\mathrm{Cu}$-SOCBP was as high as $M_{\mathrm{w}}=6.5 \times 10^{6} \mathrm{Da}$, which might be an indication of the formation of the supramolecule complexes (See Supplementary Materials about the test method). The synthetic routes for monomers OCBP and Cu-SOCBP are shown in Scheme 1.

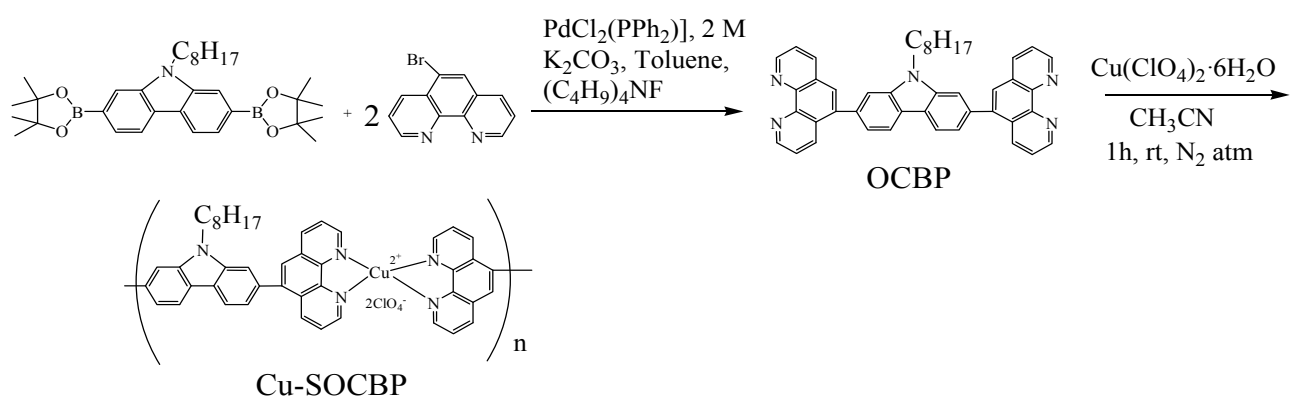

Scheme 1. Synthetic routes for the ligand OCBP and the supramolecule Cu-SOCBP.

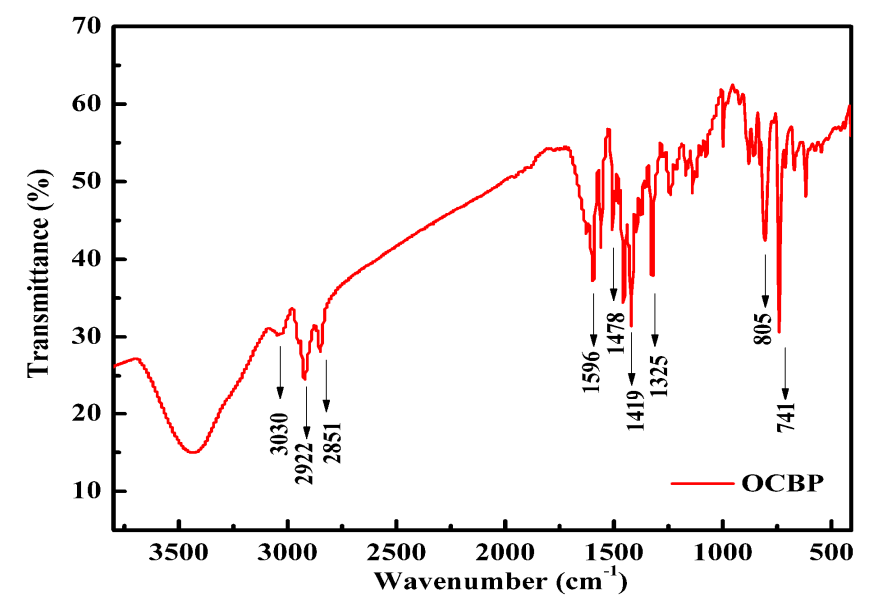

Figure 12. IR spectrum of OCBP.

\subsection{Catalyst Preparation}

Cu-SOCBP solution $(200 \mu \mathrm{L})$, carbon black (Vulcan XC-72, $1.6 \mathrm{mg})$, isopropanol (177 $\mu \mathrm{L})$, nafion solution $(3 \mu \mathrm{L})$, and ultrapure water $(570 \mu \mathrm{L})[17,23]$ were mixed in a 1.5-mL Eppendorf tube to prepare a black slurry. The obtained black slurry was ultrasonically dispersed in an ultrasonic cleaner for 
one hour and then ready for further application; it is denoted as the Cu-SOCBP/C catalyst slurry. In the procedure to modify the electrode, $10 \mu \mathrm{L}$ of the above slurry was dropped on the surface of a glassy carbon (GC) disk electrode or a rotating ring-disk electrode (RRDE) and then dried at room temperature. Finally, the uniform film of the Cu-SOCBP/C catalyst was formed on the working electrode, and the loading density of the catalyst was $0.048 \mathrm{mg} \cdot \mathrm{cm}^{-2}$. For comparative purposes, a Pt/C catalyst ink was also prepared in a 1.5-mL Eppendorf tube and had the following constituents: $1 \mathrm{mg}$ of $\mathrm{Pt} / \mathrm{C}, 177 \mu \mathrm{L}$ of isopropanol, $3.5 \mu \mathrm{L}$ of nafion solution ( $5 \mathrm{wt} \%$ ), and $570 \mu \mathrm{L}$ of ultrapure water $[17,23]$. The Pt/C link catalyst was dispersed using this same method. Catalyst ink $(10 \mu \mathrm{L})$ was dropped on the working electrode $\left(\mathrm{Pt}=15 \mu \mathrm{g} \mathrm{cm}{ }^{-2}\right)$ to prepare the $\mathrm{Pt} / \mathrm{C}$-modified electrode, which was then dried for use. The prepared electrodes were subjected to cyclic voltammetry $(\mathrm{CV})$, linear sweep voltammetry (LSV), and RRDE measurements. Before electrode modification, the surface of the working electrode must be polished using $\mathrm{Al}_{2} \mathrm{O}_{3}(0.3 \mu \mathrm{m})$ and then washed with ultrapure water to obtain a clean surface.

\subsection{Physical Characterization and Electrochemical Studies}

${ }^{1} \mathrm{H}$ NMR and ${ }^{13} \mathrm{C}$ NMR spectra of OCBP were recorded in $\mathrm{CDCl}_{3}$ at $400 \mathrm{MHz}$ using a Varian AMX 400 spectrometer (Varian Inc., Santa Clara, CA, USA), and tetramethylsilane was used as the internal standard. Fourier transform infrared (FT-IR) spectra were recorded using a Nicolet $170 \mathrm{SX}$ FTIR spectrometer (Thermo Fisher Scientific Inc., Waltham, MA, USA) with samples embedded in $\mathrm{KBr}$ pellets. To gain information on the microstructures of the catalyst, the catalyst was uniformly dispersed on the surface of Indium tin oxide (ITO)-coated glass, and scanning electron microscopy (SEM) was recorded using a ZEISS scanning electron microscope(SEM, Carl Zeiss Ltd., Oberkochen, Germany). X-ray photoelectron spectroscopy (XPS, ESCALAB $250 \mathrm{Xi}$, Thermo Fisher Scientific Inc., Waltham, MA, USA) was used to analyze the elemental compositions of the samples and the valence states of those elements. Electrochemical measurements were all taken using a computer-controlled Autolab potentiostat/galvanostat (PGSTAT302N, Metrohm Autolab, The Netherlands). A standard three-electrode electrochemical system was used, in which a GC electrode (diameter, $5 \mathrm{~mm}$ ) or RRDE (outer diameter $7.92 \mathrm{~mm}$, inner diameter $6.25 \mathrm{~mm}$ ) was used as the working electrode, an $\mathrm{Ag} / \mathrm{AgCl}$ (saturated potassium chloride) $(0.197 \mathrm{~V}+0.0591 \times \mathrm{pH}$ vs. reversible hydrogen electrode (RHE) at $25^{\circ} \mathrm{C}$ ) electrode was used as the reference electrode, and a platinum electrode was used as the counter electrode [41]. The testing medium used as the electrolyte was $0.1 \mathrm{M}$ phosphate buffer solution (PBS), and as required by the tests, the electrolyte medium was saturated with oxygen or nitrogen gas, which was provided by a gas supply device alongside the electrochemical testing system. The XRD spectra were measured by a XD-3 Purkinje diffractometer (Beijing Purkinje General Instrument Co. Ltd., Beijing, China), employing monochromatized Cu $\mathrm{K}_{\mathrm{a} 1}$ radiation, and the scan rate was $4^{\circ} / \mathrm{min}$ over the range of $2 \theta=10-60^{\circ}$. The physisorption test was conducted on a TriStar II 3020 specific surface and pore analyzer.

\section{Conclusions}

A type of copper-based metallo-supramolecule polymer was prepared via the coordination reaction of copper ions and a new bis(1,10-phenanthroline)-containing ligand. The polymer had a high content of pyridine-type nitrogen and $\mathrm{Cu}-\mathrm{N}_{x}$ units. The polymer was loaded on carbon black using a simple blending method to prepare a novel ORR catalyst, and the aim was to enhance conductivity and the mass transfer capacity. ORR activities and the underlying mechanisms of the catalyst were characterized in detail using CV, RDE, and RRDE methods as well as a comprehensive analysis of the data. The results show that $\mathrm{Cu}-\mathrm{SOCBP} / \mathrm{C}$ performs an electrocatalytic reduction to oxygen with a predominantly four-electron transfer process. RRDE measurements further confirmed the direct four-electron transfer pathway for the reduction of oxygen to water. In all, the polymer-based catalyst is an alternative choice for the commercial $\mathrm{Pt} / \mathrm{C}$ in the application of fuel cells, such as microbial fuel cells that operate in an aqueous buffer solution. 
Supplementary Materials: The following are available online at http:/ / www.mdpi.com/2073-4344/8/2/23/s1, The molecular weight measurement of Cu-SOCBP; Figure S1: CV of Vulcan XC-72 modified electrode in PBS solution saturated with $\mathrm{N}_{2}$ or $\mathrm{O}_{2}$; Figure S2. Polarization curves of Vulcan XC-72 modified electrode at different rotating rates in $\mathrm{O}_{2}$ saturated electrolyte; Figure S3: The K-L plots of Vulcan XC-72 carbon modified electrode at the potentials of $0.1 \mathrm{~V}, 0.0 \mathrm{~V}$, and $-0.1 \mathrm{~V}$, respectively; Figure S4. RRDE curves (a), the yield of $\mathrm{H}_{2} \mathrm{O}_{2}(\%)(\mathrm{b})$, and electron transfer number (c) of $\mathrm{Pt} / \mathrm{C}(20 \%)$; Table S1. The fitting equations and the values of $\mathrm{R}^{2}$ in the K-L plots of the catalysts.

Acknowledgments: The work was financially supported by the National Natural Science Foundation of China (51473074, 31400044), the doctoral fund projects Dongchang College, Liaocheng University (J17BS0001), the science and technology project in colleges and universities in Shandong Province (J17KA098), and the open foundation of State Key Laboratory of Heavy Oil Processing (SKLOP201602004), College of Chemical Engineering, China University of Petroleum.

Author Contributions: Yuanyuan Zhao supervised the instrumental analysis and drafted the first edition of the manuscript; Ya Chu synthesized the ligand and prepared the metallo-supramolecular polymer. Xiuping Ju conducted the electrochemical measurements. Jinsheng Zhao provided the idea of the manuscript and provided the required reagents and instruments. Lingqian Kong polished the language of the manuscript. Yan Zhang helped with the analyzing of all kinds of data.

Conflicts of Interest: The authors declare no conflict interest.

\section{References}

1. Kato, M.; Oyaizu, N.; Shimazu, K.; Yagi, I. Oxygen Reduction Reaction Catalyzed by Self-Assembled Monolayers of Copper-Based Electrocatalysts on a Polycrystalline Gold Surface. J. Phys. Chem. C 2016, 120, 15814-15822. [CrossRef]

2. Wang, J.; Wang, T.T.; Wang, F.B.; Zhang, D.Y.; Wang, K.; Xia, X.H. Exploration of the Copper Active Sites in Electrooxidation of Glucose on a Copper/Nitrogen Doped Graphene Nanocomposite. J. Phys. Chem. C 2016, 120, 15593-15599. [CrossRef]

3. Gartia, Y.; Parnell, C.M.; Watanabe, F.; Szwedo, P.; Biris, A.S.; Peddi, N.; Ghosh, A. Graphene-enhanced oxygen reduction by $\mathrm{MN}_{4}$ type Cobalt(III) catalyst. ACS Sustain. Chem. Eng. 2014, 3, 97-102. [CrossRef]

4. Guo, C.Z.; Liao, W.L.; Sun, L.T.; Chen, C.G. Synthesis of non-noble nitrogen-containing catalysts for cathodic oxygen reduction reaction: A critical review. Int. J. Electrochem. Sci. 2015, 10, 2467-2477.

5. Nie, Y.; Li, L.; Wei, Z.D. Recent advancements in Pt and Pt-free catalysts for oxygen reduction reaction. Chem. Soc. Rev. 2015, 44, 2168-2201. [CrossRef] [PubMed]

6. Sun, T.; Wu, Q.; Che, R.; Bu, Y.; Jiang, Y.; Li, Y.; Yang, L.J.; Wang, X.Z.; Hu, Z. Alloyed Co-Mo Nitride as High-Performance Electrocatalyst for Oxygen Reduction in Acidic Medium. ACS Catal. 2015, 5, 1857-1862. [CrossRef]

7. Panomsuwan, G.; Saito, N.; Ishizaki, T. Electrocatalytic oxygen reduction on nitrogen-doped carbon nanoparticles derived from cyano-aromatic molecules via a solution plasma approach. Carbon 2016, 98, 411-420. [CrossRef]

8. Othman, R.; Dicks, A.L.; Zhu, Z. Non precious metal catalysts for the PEM fuel cell cathode. Int. J. Hydrogen Energy 2012, 37, 357-372. [CrossRef]

9. Zhang, Z.X.; Zhang, Y.X.; Mu, X.M.; Du, J.W.; Wang, H.; Huang, B.Y.; Zhou, J.Y.; Pan, X.J.; Xie, E.Q. The carbonization temperature effect on the electrochemical performance of nitrogen-doped carbon monoliths. Electrochim. Acta 2017, 242, 100-106. [CrossRef]

10. Chen, Y.C.; Gokhale, R.; Serov, A.; Artyushkova, K.; Atanassov, P. Novel highly active and selective Fe-N-C oxyen reduction electrocatalysts derived from in-situ polymerization pyrolysis. Nano Energy 2017, 38, 201-209. [CrossRef]

11. Sarapuu, A.; Samolberg, L.; Kreek, K.; Koel, M.; Matisen, L.; Tammeveski, K. Cobalt-and iron-containing nitrogen-doped carbon aerogels as non-precious metal catalysts for electrochemical reduction of oxygen. J. Electroanal. Chem. 2015, 746, 9-17. [CrossRef]

12. Liang, Y.; Wang, H.; Zhou, J.; Li, Y.; Wang, J.; Regier, T.; Dai, H. Covalent hybrid of spinel manganese-cobalt oxide and graphene as advanced oxygen reduction electrocatalysts. J. Am. Chem. Soc. 2012, 134, 3517-3523. [CrossRef] [PubMed]

13. Zhang, Y.L.; Zhao, L.Z.; Walton, J.; Liu, Z.; Tang, Z. Facile fabrication of PtPd alloyed worm-like nanoparticles for electrocatalytic reduction of oxygen. Int. J. Hydrogen Energy 2017, 42, 17112-17121. [CrossRef] 
14. Kato, M.; Kimijima, K.I.; Shibata, M.; Notsu, H.; Ogino, K.; Inokuma, K.; Ohba, T. Deprotonation of a dinuclear copper complex of 3,5-diamino-1,2,4-triazole for high oxygen reduction activity. Phys. Chem. Chem. Phys. 2015, 17, 8638-8641. [CrossRef] [PubMed]

15. Jiang, L.; Li, M.; Lin, L.; Li, Y.; He, X.; Cui, L. Electrocatalytic activity of metalloporphyrins grown in situ on graphene sheets toward oxygen reduction reaction in an alkaline medium. RSC Adv. 2014, 4, 26653-26661. [CrossRef]

16. Ou, Z.P.; Lü, A.X.; Meng, D.Y.; Huang, S.; Fang, Y.Y.; Lu, G.F.; Kadish, K.M. Molecular oxygen reduction electrocatalyzed by meso-substituted cobalt corroles coated on edge-plane pyrolytic graphite electrodes in acidic media. Inorg. Chem. 2012, 51, 8890-8896. [CrossRef] [PubMed]

17. He, H.Y.; Wang, M.; Zhao, J.S.; Zhang, Y. Poly(10,12-bis (4-hexylthiophene-2-yl)thieno[3' $\left.{ }^{\prime} 4^{\prime}: 5,6\right]$ pyrazino[2,3-F] $[1,10]$-phenanthroline-copper(II) complex as an efficient electrocatalyst for oxygen reduction. Chem. Eng. J. 2017, 316, 680-691. [CrossRef]

18. Ren, C.C.; Li, H.B.; Li, R.; Xu, S.L.; Wei, D.H.; Kang, W.J.; Wang, L.; Jia, L.P.; Yang, B.C.; Liu, J.F. Electrocatalytic study of a 1,10-phenanthroline-cobalt(II) metal complex catalyst supported on reduced graphene oxide towards oxygen reduction reaction. RSC Adv. 2016, 6, 33302-33307. [CrossRef]

19. Passard, G.; Ullman, A.M.; Brodsky, C.N.; Nocera, D.G. Oxygen reduction catalysis at a dicobalt center: The relationship of faradic efficiency to overpotential. J. Am. Chem. Soc. 2016, 138, 2925-2928. [CrossRef] [PubMed]

20. Lee, K.; Zhang, L.; Lui, H.; Hui, R.; Shi, Z.; Zhang, J.J. Oxygen reduction reaction (ORR) catalyzed by carbon-supported cobalt polypyrrole (Co-PPy/C) electrocatalysts. Electrochim. Acta 2009, 54, 4704-4711. [CrossRef]

21. Lei, H.T.; Liu, C.Y.; Wang, Z.J.; Zhang, Z.Y.; Zhang, M.N.; Chang, X.M.; Zhang, W.; Cao, R. Noncovalent immobilization of a pyrene-modified cobalt corrole on carbon supports for enhanced electrocatalytic oxygen reduction and oxygen evolution in aqueous solution. ACS Catal. 2016, 6, 6429-6437. [CrossRef]

22. Wang, F.F.; Wei, P.J.; Yu, G.Q.; Liu, J.G. Titanium Dioxide-Grafted Copper Complexes: High-Performance Electrocatalysts for the Oxygen Reduction Reaction in Alkaline Media. Chem. Eur. J. 2016, 22, 382-389. [CrossRef] [PubMed]

23. Yu, J.F.; Lu, Y.Q.; Yuan, C.G.; Zhao, J.S.; Wang, M.; Liu, R.M. Carbon supported polyindole-5-carboxylic acid covalently bonded with pyridine-2, 4-diamine copper complex as a non-precious oxygen reduction catalyst. Electrochim. Acta 2014, 143, 1-9. [CrossRef]

24. Levy, N.; Mahammed, A.; Friedman, A.; Gavriel, B.; Gross, Z.; Elbaz, L. Metallocorroles as non-precious metal electrocatalysts for highly efficient oxygen reduction in alkaline media. ChemCatChem 2016, 8, 2832-2837. [CrossRef]

25. Levy, N.; Mahammed, A.; Kosa, M.; Major, D.T.; Gross, Z.; Elbaz, L. Metallocorroles as nonprecious metal catalysts for oxygen reduction. Angew. Chem. Int. Ed. 2015, 54, 14080-14084. [CrossRef] [PubMed]

26. Thorseth, M.A.; Tornow, C.E.; Tse, E.C.M.; Gewirth, A.A. Cu complexes that catalyze the oxygen reduction reaction. Coord. Chem. Rev. 2013, 257, 130-139. [CrossRef]

27. Zhong, J.P.; Fan, Y.J.; Wang, H.; Wang, R.X.; Fan, L.L.; Shen, X.C.; Shi, Z.J. Copper phthalocyanine functionalization of graphene nanosheets as support for platinum nanoparticles and their enhanced performance toward methanol oxidation. J. Power Sources 2013, 242, 208-215. [CrossRef]

28. Huang, Y.; Wang, Y.; Li, Z.; Yang, Z.; Shen, C.; He, C. Effect of Pore Morphology on the Dielectric Properties of Porous Carbons for Microwave Absorption Applications. J. Phys. Chem. C 2014, 118, 26027-26032. [CrossRef]

29. Ferrandon, M.; Kropf, A.J.; Myers, D.J.; Artyushkova, K.; Kramm, U.; Bogdanoff, P.; Zelenay, P. Multitechnique characterization of a polyaniline-iron-carbon oxygen reduction catalyst. J. Phys. Chem. C 2012, 116, 16001-16013. [CrossRef]

30. Martínez, J.M.L.; Rodríguez-Castellón, E.; Sánchez, R.M.T.; Denaday, L.R.; Buldain, G.Y.; Dall'Orto, V.C. XPS studies on the $\mathrm{Cu}(\mathrm{I}, \mathrm{II})$-polyampholyte heterogeneous catalyst: An insight into its structure and mechanism. J. Mol. Catal. A Chem. 2011, 339, 43-51. [CrossRef]

31. Kumar, R.; Yadav, A.; Mahiya, K.; Mathur, P. Copper(II) complexes with box or flower type morphology: Sustainability versus perishability upon catalytic recycling. Inorg. Chim. Acta 2016, 450, 279-284. [CrossRef]

32. Yang, L.; Su, Y.; Li, W.; Kan, X. Fe/N/C Electrocatalysts for Oxygen Reduction Reaction in PEM Fuel Cells Using Nitrogen-Rich Ligand as Precursor. J. Phys. Chem. C 2015, 119, 11311-11319. [CrossRef] 
33. Huang, H.; Wang, X. Pd nanoparticles supported on low-defect graphene sheets: For use as high-performance electrocatalysts for formic acid and methanol oxidation. J. Mater. Chem. 2012, 22, 22533-22541. [CrossRef]

34. Fan, T.Y.; Yin, F.X.; Wang, H.; He, X.B.; Li, G.R. A metal-organic-framework/carbon composite with enhanced bifunctional electrocatalytic activities towards oxygen reduction/evolution reactions. Int. J. Hydrogen Energy 2017, 42, 17376-17385. [CrossRef]

35. Ju, J.; Bo, X.J.; Wang, H.; Zhang, Y.F.; Luhana, C.; Guo, L.P. Poly-o-toluidine cobalt supported on ordered mesoporous carbon as an efficient electrocatalyst for oxygen reduction. Electrochem. Commun. 2012, 25, 35-38. [CrossRef]

36. Li, T.F.; Peng, Y.X.; Li, K.; Zhang, R.; Zheng, L.R.; Xia, D.G.; Zuo, X. Enhanced activity and stability of binuclear iron(III) phthalocyanine on graphene nanosheets for electrocatalytic oxygen reduction in acid. J. Power Sources 2015, 293, 511-518. [CrossRef]

37. Wu, J.J.; Zhang, D.; Niwa, H.; Harada, Y.; Oshima, M.; Ofuchi, H.; Nabae, Y.; Okajima, T.; Ohsaka, T. Enhancement in Kinetics of the Oxygen Reduction Reaction on a Nitrogen-Doped Carbon Catalyst by Introduction of Iron via Electrochemical Methods. Langmuir 2015, 31, 5529-5536. [CrossRef] [PubMed]

38. Parimi, N.S.; Umasankar, Y.; Atanassov, P.; Ramasamy, R.P. Kinetic and mechanistic parameters of laccase catalyzed direct electrochemical oxygen reduction reaction. ACS Catal. 2011, 2, 38-44. [CrossRef]

39. Hossain, M.D.; Sato, D.T.; Higuchi, D.M. A Green Copper-Based Metallo-Supramolecular Polymer: Synthesis, Structure, and Electrochromic Properties. Chem. Asian J 2013, 8, 76-79. [CrossRef] [PubMed]

40. Glatfelter, A.; Dybowski, C.; Bai, S.; Kragten, D.; Blake, M.J.; Segarra, S.; Perry, D.L. Infrared studies of lead(II) halide-1,10-phenanthroline photosensitive materials. Sprctrochim. Acta A 2009, 71, 1922-1926. [CrossRef] [PubMed]

41. Yan, Z.H.; Wang, M.; Liu, J.F.; Liu, R.M.; Zhao, J.S. Glycerol-stabilized $\mathrm{NaBH}_{4}$ reduction atroom-temperature for the synthesis of a carbon-supported PtxFe alloy with superior oxygen reduction activity for a microbial fuel cell. Electrochim. Acta 2014, 141, 331-339. [CrossRef] 